Combined Raman spectroscopic and Rietveld analyses as a useful and nondestructive approach to studying flint raw materials at prehistoric archaeological sites

C. Capel Ferrón, L. León-Reina, S. JorgeVillar, J. M. Compaña, M. A. G. Aranda, J. T. López Navarrete, V. Hernández, et al.

Archaeological and Anthropological Sciences

ISSN 1866-9557

Archaeol Anthropol Sci

DOI 10.1007/s12520-014-0189-0

\section{ONLINE FIRST}

Archaeological and Anthropological Sciences

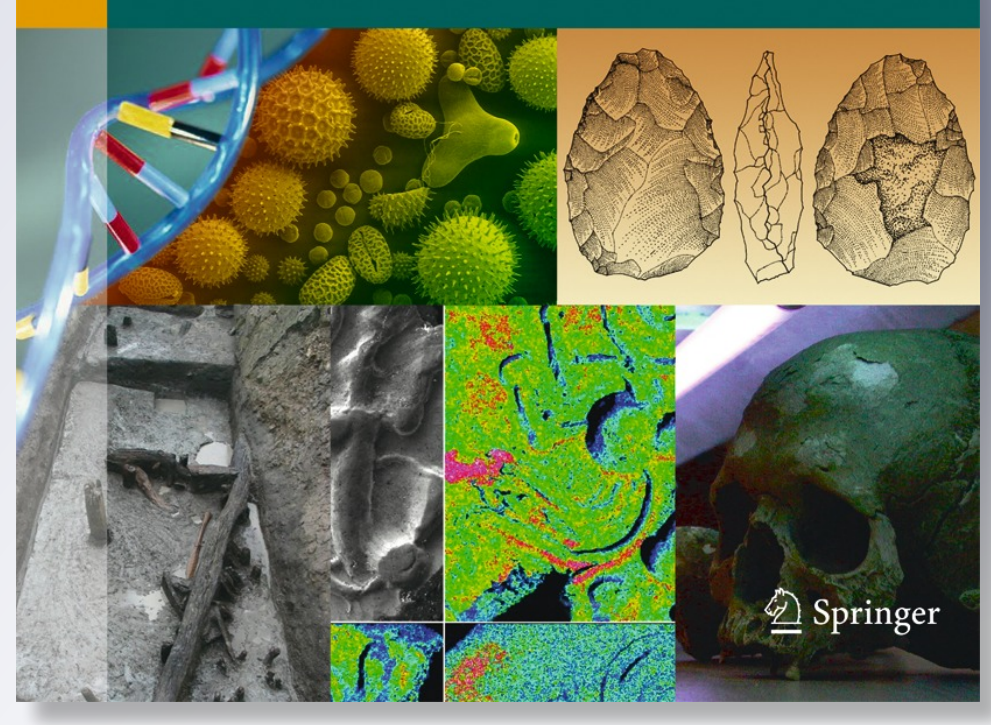

算 Springer 
Your article is protected by copyright and all rights are held exclusively by SpringerVerlag Berlin Heidelberg. This e-offprint is for personal use only and shall not be selfarchived in electronic repositories. If you wish to self-archive your article, please use the accepted manuscript version for posting on your own website. You may further deposit the accepted manuscript version in any repository, provided it is only made publicly available 12 months after official publication or later and provided acknowledgement is given to the original source of publication and a link is inserted to the published article on Springer's website. The link must be accompanied by the following text: "The final publication is available at link.springer.com". 


\title{
Combined Raman spectroscopic and Rietveld analyses as a useful and nondestructive approach to studying flint raw materials at prehistoric archaeological sites
}

\author{
C. Capel Ferrón • L. León-Reina • S. Jorge-Villar • J. M. Compaña • M. A. G. Aranda • \\ J. T. López Navarrete • V. Hernández • F. J. Medianero • J. Ramos • G.-C. Weniger • \\ S. Domínguez-Bella • J. Linstaedter · P. Cantalejo • M. Espejo • J. J. Durán Valsero
}

Received: 7 October 2013 / Accepted: 24 February 2014

(C) Springer-Verlag Berlin Heidelberg 2014

\begin{abstract}
A set of six lithic tools, unearthed along 2011 in two karst sites of the Guadalteba County (Málaga, Spain), has been nondestructively investigated by Raman spectroscopy and laboratory x-ray diffraction. From a chemist's point of view, our goal is to develop a systematic screening protocol for a quick, easy, low cost and nondestructive characterization of archaeological flints based on Raman spectroscopy, x-ray diffraction and Rietveld refinement. In this paper, we firstly made use of Raman spectroscopy to determine, in a semiquantitative way, but with the generic advantage of a faster
\end{abstract}

\section{Capel Ferrón}

Laboratorio de Espectroscopía Vibracional, Servicios Centrales de

Apoyo a la Investigación, Universidad de Málaga, Campus de

Teatinos, s/n, 29071 Málaga, Spain

\section{León-Reina}

Laboratorio de Difracción de rayos-X, Servicios Centrales de Apoyo a la Investigación, Universidad de Málaga, Campus de Teatinos, s/n, 29071 Málaga, Spain

S. Jorge-Villar

Área de Geodinámica Interna, Facultad de Humanidades y

Educación, Universidad de Burgos, C/ Villadiego s/n, 09001 Burgos, Spain

S. Jorge-Villar $(\bowtie)$

National Research Center on Human Evolution (CENIEH), Burgos, Spain

e-mail: seju@ubu.es

J. M. Compaña • M. A. G. Aranda

Departamento de Química Inorgánica, Cristalografía y Mineralogía, Facultad de Ciencias, Universidad de Málaga, Campus de Teatinos, s/n, 29071 Málaga, Spain

J. T. López Navarrete $\cdot$ V. Hernández $(\bowtie)$

Departamento de Química Física, Facultad de Ciencias, Universidad de Málaga, Campus de Teatinos, s/n, 29071 Málaga, Spain

e-mail: hernandez@uma.es data acquisition than x-ray diffraction, the surface content of moganite of each lithic tool, from the ratio between the relative intensities of the two Raman-active symmetric stretching vibrations $\left(\mathrm{A}_{1}\right.$ modes $)$ of $\alpha$-quartz $\left(465 \mathrm{~cm}^{-1}\right)$ and moganite $\left(501 \mathrm{~cm}^{-1}\right)$. The precise bulk quartz/moganite weight content was then accurately quantified by means of high-quality $x$-ray diffraction, followed by Rietveld refinement. We found a general good correlation between Raman and x-ray data. Nonetheless, as recently reported in the scientific literature by other authors, the vibrational spectroscopic quantification

\section{F. J. Medianero}

Escuela Taller de Peñarrubia, Consorcio Guadalteba, Paseo de Peñarrubia, s/n, 29320, Campillos Málaga, Spain

\section{J. Ramos}

Área de Prehistoria, Facultad de Filosofia y Letras, Universidad de Cádiz, Avda. Gómez Ulla, s/n, 11003 Cádiz, Spain

\section{G.-C. Weniger}

Stiftung Neanderthal Museum, Talstrasse, 300, 40822 Mettman, Germany

S. Domínguez-Bella

Departamento de Ciencias de la Tierra, Universidad de Cádiz, Campus Rio San Pedro, 11510, Puerto Real Cádiz, Spain

J. Linstaedter Institute of Prehistoric Archaeology, University of Cologne, Weyertal 125, 50923 Cologne, Germany

P. Cantalejo $\cdot$ M. Espejo

Red Patrimonio Guadalteba, Consorcio Guadalteba, Paseo de Peñarrubia, s/n, 29320, Campillos Málaga, Spain

J. J. D. Valsero

Instituto Geológico y Minero de España (IGME), C/ Ríos Rosas, 23, 28003 Madrid, Spain 
of moganite in silica rocks like flint and chert have to be performed very cautiously, to avoid undesired interferences from other Raman features due to the eventual presence of silanol $(\mathrm{SiOH})$ groups, which could finally lead to an overestimation of the surface moganite concentration. As reported in such a recent article, a useful treatment to reduce the interference from silanol-bands is to heat the samples prior to their Raman analysis at a minimum of $600^{\circ} \mathrm{C}$ (but better at 700 or $800^{\circ} \mathrm{C}$ ) for silanol "dehydration". This, in our opinion, may be for sure a satisfactory procedure when studying flint or chert samples of a "geological origin". But not of practical use when studying lithic tools which were manufactured by men thousands and thousands of years ago.

Keywords Raman spectroscopy $\cdot$ X-ray diffraction $\cdot$ Rietveld analysis · Quartz · Moganite · Archaeometry $\cdot$ Lithic tools . Flint

\section{Introduction}

A very abundant and continuous human occupation has been documented in the Guadalteba County (Málaga, Spain), with a chronologic sequence extending from the Middle Pleistocene to modern times (Fig. 1). The archaeological studies performed so far in this Andalusian area have been mainly focused on the cleaning, prospecting and excavation works conducted in the karst site of Las Palomas cave in Teba (Medianero et al. 2011), as well as at the nearby Ardales cave over the past 25 years. Recently, all these on-site archaeological works have allowed the awarding of the research project, "The Guadalteba Project", by the Junta de Andalucía regional government, one of whose main aim is the routinary use of modern and nondestructive archaeometric techniques as a help to the scientific and archaeological research of the prehistoric heritage of the Guadalteba County.

In a previous investigation, we analysed by Raman spectroscopy the bulks and patinas of a series of flintmanufactured artefacts from the Guadalteba County (Hernández et al. 2012). The final goal of that previous work was checking if this fast, nondestructive and sample preparation-free vibrational spectroscopic technique could provide useful information about the mineral composition of the chert tools as well as some information about their assignment to distinctive groups of raw materials of a particular provenance. On the basis of the vibrational data reported in that archaeometric Raman study, it was confirmed that $\alpha$ quartz was the main phase in the flints under study, although a small amount of moganite was also evidenced as a distinctive fingerprint in some specimens (Hernández et al. 2012).

On the other hand, x-ray diffraction studies of microcrystalline quartz have been also addressed in the archaeometric literature for lithic sourcing. Based on earlier works, some authors have applied the Rietveld method to quantify the silica polymorph ratios for sourcing chert and chalcedony lithic materials (Heaney and Post 1992; Pretola 2001). Initially, diffraction data on powdered samples were taken for a better profile shape and particle averaging. Advances in the optic setup(s) of modern diffractometers allow collection of x-ray diffraction data directly from the bulk of the flint (polycrystalline) samples if at least one pseudo-flat surface is present. In this regard, we can highlight the nondestructive analysis of the quartz/moganite content ratio of Roman silica gemstones, on the own bulk samples (Gliozzo et al. 2011). Xray diffraction has also been recently used for analysing flints and other raw lithic materials, with data directly collected on flint bulk specimens (Graetsch and Grünberg 2012).

Flints and cherts have extensively been used as raw materials for production of lithic industry since the Palaeolithic. However, to nonexperts, there is no sharp mineralogical distinction between them: both consist of microfibrous chalcedonic silica. Flint usually occurs in the form of macroscopic nodules, several centimetres thick and forming discontinuous layers in chalk or limestone. Geologically, the name is restricted to Cretaceous European formations. On the other hand, chert is often found as bedded massy, sometimes layered deposits (Frondel, 1962), but also in nodular form. The term "chert" is used more broadly and may include rocks with a microgranular rather than a microfibrous microstructure as well as flint.

Moganite is a naturally abundant silica polymorph which has been found in silica rocks all over the world, mainly intimately intergrown with chalcedony (Heaney and Post 1992; Heaney 1995), and which was identified in pure form only on Gran Canaria Island, Spain (Flörke et al. 1976; Jambor et al. 1993; Kingma and Hemley 1994; Götze et al. 1998), where it occurs in fractures and voids within the rhyolite ignimbrite flows of the Mogán Formation. Moganite was definitively accepted as a new mineral member of the silica system in 1999 (IMA N ${ }^{\circ}$ 99-035). Moganite can be distinguished from $\alpha$-quartz by LXRD on the basis of its crystal structure (Heaney and Post 2001) and, hence, its unique diffraction pattern (lattice parameters at room temperature: $a=8.737 \AA, b=4.869 \AA$, $c=10.722 \AA$ and $\theta=90.19$ ) (Heaney and Post 2001). Moganite is nowadays recognised as a common intergrowth in many types of cherts used as raw materials during prehistoric times in different locations of the Iberian Peninsula (Gutiérrez et al. 1991; Olivares et al. 2009; Bustillo et al. 2012; Bustillo 2001; Tarriño et al. 2007).

In this work, we analyse by means of nondestructive archaeometric techniques such as Raman spectroscopy and Rietveld methodology six lithic tools collected from two different karst sites of the Guadalteba County (Málaga, Spain). Our main goal is to develop a systematic protocol for a fast and non-destructive characterization of archaeological flints, with the hope that it might provide a scientific basis 
Fig. 1 Geographic setting of the Guadalteba County (Málaga, Spain). Photographs on the left show the scaffold at the entry of Las Palomas de Teba Cave as well as some views of Tajo del Molino and La Venta River. Photographs at the centre display a view of the large fallen blocks inside of Las Palomas de Teba Cave as well as other five views from the top and bottom of Sima de las Palomas before and after the installation of the stable scaffold and the grille at its entry. Finally, photographs at the right show other two views of the great cone of sediments just at the current mouth of the Ardales Cave (opened after the earthquake of 1821) and some representative examples of its several manifestations of prehistoric art (such as negative hand stencils and an engraved hind)

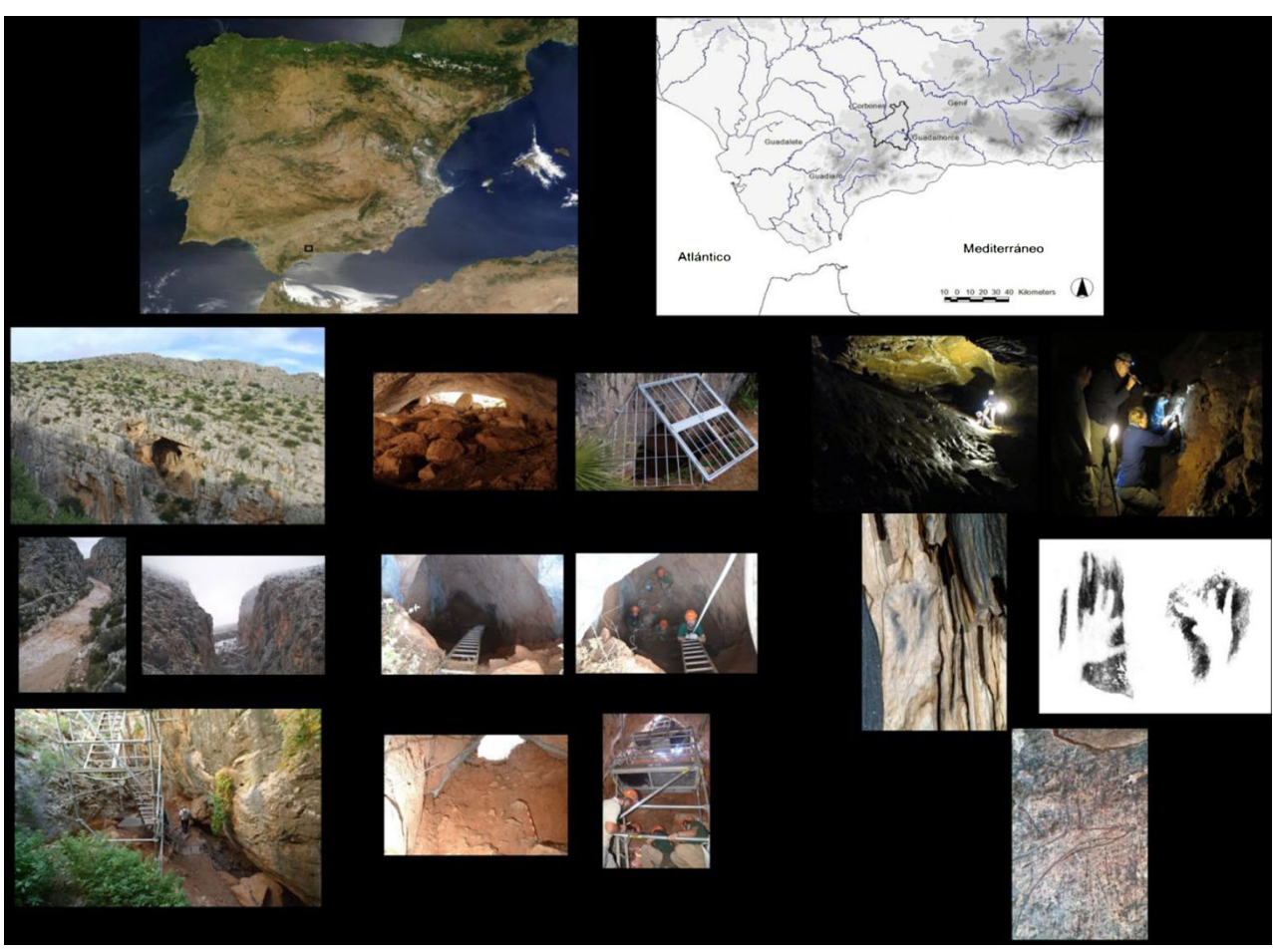

for future works on raw material procurement pattern analyses.

Archaeological context and geological setting

Over the past 10 years, around 70,000 lithic tools have been found during the systematic and exhaustive stratigraphic study of the low terraces of the Guadalteba river. The specimens can be attributed to different chronologic periods including: (1) Acheulean industry (cores, flakes, bifaces and retouched products) (Carbonell et al. 1999; Clark 1998; Laplace 1975), which were also documented as belonging to Mode II-Old Iberian Acheulean and Plenum Iberian Acheulean (Vallespí 1986a; Vallespí 1986b; Vallespí 1992) and (2) Mode III-Mousterian technology (cores, Levallois flakes, and among the retouched products: scrapers, notches and points). The huge number of stone tools and other archaeological objects already found in these privileged lands (such as human bones, wall paintings and engravings in caves, stone lamps, remains of fire-linked activities, etc.) are indicative of an abundant and continuous occupation of this territory by pre-Neanderthal huntergatherer societies and Neanderthals, who lived in the middle and high Guadalhorce river areas, hunting large mammals.

The Ardales cave, which is known worldwide for its numerous manifestations of Palaeolithic art, has a great cone of sediments of high archaeological interest located just at its current entry. The nearby karst complex of Las Palomas de Teba contains another vertical stratigraphic deposit of nearly $8 \mathrm{~m}$ in depth (in a place known as "Sima de las Palomas") which is particularly rich in bones, manufactured stone tools and some other evidences of Pleistocene human occupation, characteristic of Neanderthal occupation.

The karst complex of Las Palomas de Teba is located in the West Peñarrubia Mountains, in a gorge known as Tajo del Molino (Fig. 1). This karst complex is developed in limestones sediments of the inner Subbetic, showing a thick calcareous series of Jurassic age composed by red coloured nodular and brechoid Malm limestones, followed by Cretaceous (Coniacian-Maastrichtian) "red beds" characteristic of the Betic Chain. The cave was formed by the karstification of Sierra de Teba and includes a collapsed doline as well as several galleries that are not particularly rich in speleothems. Above the speleothem horizon, there is a horizon of clays and debris, followed by cemented limestone breccias that are surmounted by large fallen blocks (Medianero et al. 2011).

The Ardales Cave is located around $20 \mathrm{~km}$ from Las Palomas de Teba Cave and $2 \mathrm{~km}$ from the Ardales village, in the Cerro de la Calinoria, part of the Serrezuela mountain range. The cave was sealed by an earthquake around 8,000 years ago and rediscovered after another earthquake in 1821 , which revealed its current mouth. The cave is $1,577 \mathrm{~m}$ long and is formed by Triassic calcareous rocks of uncertain 
paleogeographic attribution, although they belong to the internal zone of the mountain chain of Andalucía, in one of the natural paths between the Málaga Bay (south) and the Guadalquivir Depression (northwest).

\section{Material and methods}

Specimens

Lithic tools numbered as 2 and 5 were collected during the preliminary prospection works carried out during the 20112012 season at the great cone of sediments located just below the current entry of the Ardales Cave (Fig. 1 and 2). Specimen 2 is a chisel (Upper Palaeolithic) made in massive white chert, and showing small white microlithic inclusions or spicules, whereas specimen 5 is a Mousterian flake of cream flint with clear microsphere inclusions.

The other lithic tools (1, 3, 4 and 6), all of them ascribed to Mousterian technology, were unearthed from the deepest level (VIII) in Sima de Las Palomas (Fig. 1 and 2). They were documented, together with many others tools, in a rich, still unpublished, continuous sequence of Middle Palaeolithic occupations, starting from the first half of the last glacial cycle. Lithic tools 3 and 4 (both of them flakes) and 6 (core) are made of white and grey flints; while specimen 1 (core) is made of a reddish brown radiolarite.

\section{Raman spectroscopy}

Raman data were collected on a Bruker RamII FT-Raman module attached to a Vertex FT-IR spectrometer at the SCAI of the University of Málaga. The 1,064 nm laser power was kept fixed to the lowest value to avoid mineralogical changes. Typically, 3,000 Raman scans were averaged in each case to improve the signal-to-noise ratio, with a spectral resolution of $1 \mathrm{~cm}^{-1}$, and the 100 to $1,800 \mathrm{~cm}^{-1}$ spectral range was recorded. Typically, the spot size on the lithic tools was around $50 \mu \mathrm{m}$. Different spots were analysed for each specimen, with the aim of analysing the homogeneity of the moganite distribution on the surface of each lithic tool. Cortex and patinas were avoided, and only fresh surfaces were analysed.

\section{X-ray diffraction}

Laboratory x-ray diffraction (LXRD) patterns for the bulk (fresh rock from each specimen) lithic tools were recorded on a PANalytical X'Pert PRO MPD diffractometer working in reflection geometry $(\theta / 2 \theta)$ and using the $X^{\prime}$ Celerator Real Time Multiple Strip (RTMS) detector with an active length of $2.122^{\circ}$. The flints were loaded in a multipurpose holder which allows the micrometric controlled alignment of samples with an exposed surface as flat as possible. Cu-patterns were

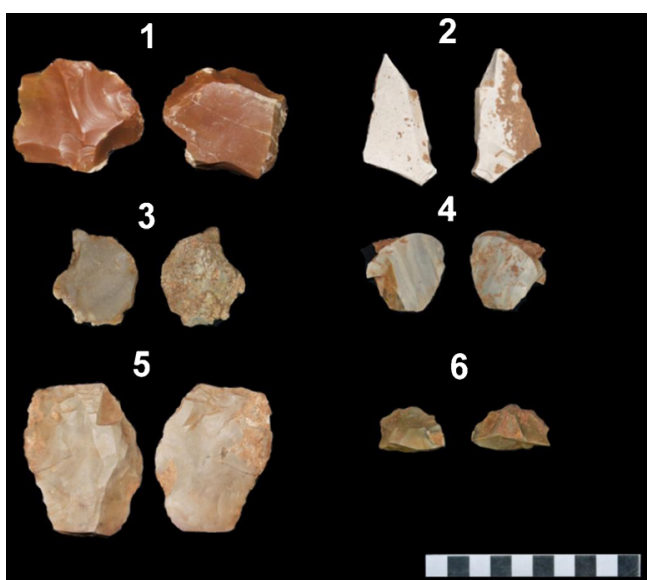

Fig. 2 Photographs of the six lithic tools subject of FT-Raman and Rietveld analysis: (1) number 1:1628-Silex-LP-perfil-2011-bulk (core); (2) number 2: 1765-AD-2-11-bulk (flake); (3) number 3: 225-230-CP-346-artefact-3-bulk (flake); (4) number 4: 1431-2011-CP-R-S-P1-bulk (flake); (5) number 5: Point-492-AD-4-11-2-CapaR-bulk (scraper); (6) number 6:1430-2011-CP-R-S-P1-bulk (waste knapping)

collected with a long fine focus $\mathrm{Cu}$ tube working at $45 \mathrm{kV}$ and $40 \mathrm{~mA}$. The incident beam optic path contained a hybrid monochromator (composed of a $\mathrm{W} / \mathrm{Si}$ parabolic $\mathrm{x}$-raygraded mirror and a 2-crystals Ge (220) 2-bounce monochromator) which yielded a monochromatic, $\lambda=1.54059 \AA$ parallel x-ray beam, and a fixed $1 / 8^{\circ}$ divergence slit. The diffracted beam optic path contained a fixed $1 / 4^{\circ}$ anti-scatter slit. Both incident and diffracted beams were equipped with $0.04 \mathrm{rad}$ Soller slits. A typical scan range was from 14.0 to $90.0^{\circ} 2 \theta$ with a step size of $0.0167^{\circ} 2 \theta$ and an overall recording time of approximately $4 \mathrm{~h}$. We recall that the diffraction data were taken on bulk lithic tools, so we can describe the setup as polycrystalline $\mathrm{x}$-ray data collection.

Polycrystalline patterns for the six lithic tools were further analysed by the Rietveld method as implemented in the GSAS-EXPGUI software package (Larson and Dreele 2000) by using a pseudo-Voigt peak shape function (Thompson et al. 1987) to obtain Rietveld Quantitative Phase Analysis (RQPA). The refined overall parameters were: phase scale factors, background coefficients, unit cell parameters, zeroshift error and peak shape parameters. Structural parameters at room temperature were taken: Will et al. (1988) for $\alpha$-quartz, Heaney and Post (2001) for moganite and Maslen et al. (1995) for calcite, and not refined further.

\section{Results and discussion}

Flint usually forms irregular nodules in sedimentary rocks. A thin white layer can surround the flint nodules. The outer layer, generally white, is sometimes denoted as cortex. Quite often, the cortex shows a powder-like appearance. Remains of this cortex layer can be seen in some of the specimens which 
Fig. 3 FT-Raman spectra of the whole series of lithic tools subject of study in the $400-550 \mathrm{~cm}^{-1}$ spectral range. Raman spectra have been shifted vertically, and scaled in intensity relative to the strongest Raman feature of $\alpha$ quartz at $465 \mathrm{~cm}^{-1}$, to make clear the variable intensity of the moganite Raman feature at $502 \mathrm{~cm}^{-1}$; and comparison between the FT-Raman profiles collected for the number 1 and number 2 specimens, at different spots on their surface

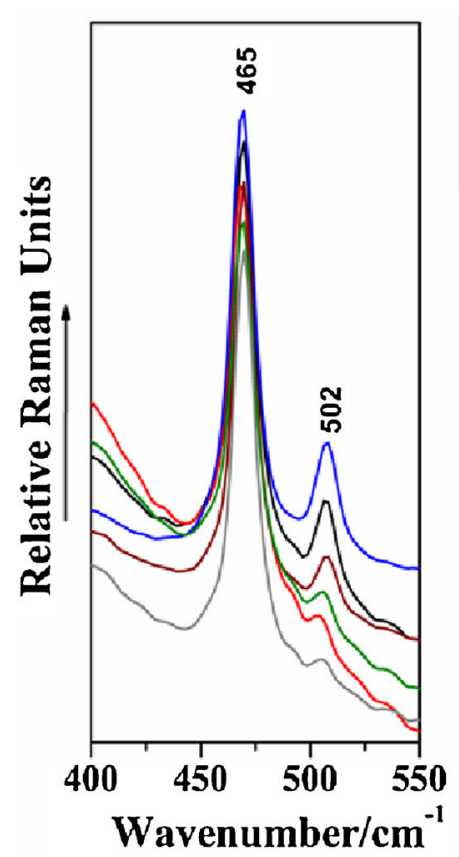

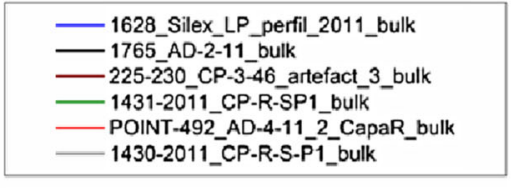
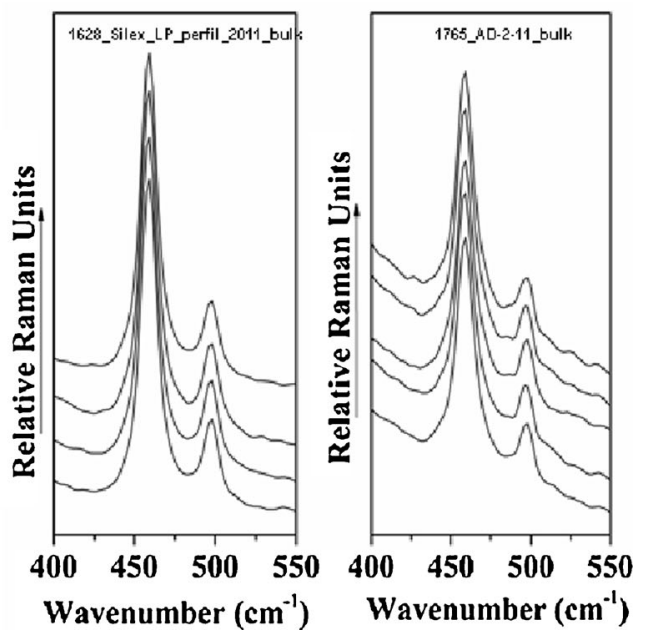

are the subject of this study (see Fig. 2). Flint (Fig 2. (2-6)) and radiolarite (Fig. 2. (1)) patinas are also present in some of the studied samples; but in general, the areas of the lithic tools with a knapping display fresh and clean surfaces. Patinas are the result of different physico-chemical transformations on the outer surface of siliceous material stone tools after their knapping process due to exposition to weathering and burial during long periods of time.

Thickness and compositional features of the surfaces of stone tools will depend on the type and composition of the original bulk raw materials (flint, radiolarite, sandstone) and also on the physico-chemical environment(s) to which they

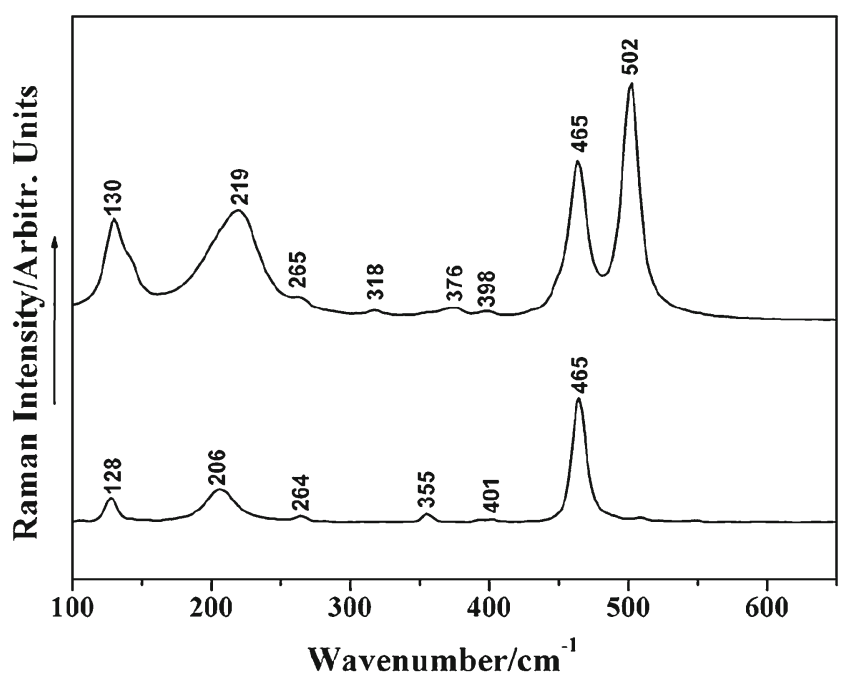

Fig. 4 FT-Raman spectra of $\alpha$-quartz (bottom) and a "moganite" sample from Mogán (Canary Islands), containing nearly $75 \%$ moganite and $25 \% \alpha$-quartz (top) as determined from a Rietveld analysis of powder diffraction data were subjected during their transport, sedimentation or burial. Quite often, a decrease of the rock density, lost or reprecipitation of silica with different morphologies or a dehydration process can occur. Furthermore, these processes can be rather heterogeneous, so slightly different data may be derived from different points on a given surface (Bustillo et al. 2007).

As bulk mineral composition is dependent on physical and chemical conditions in sedimentary areas, mineralogical characterization and phase rates of flints can be specific for each outcrop and, then, provide information about the source of the raw material.

Raman spectroscopy clearly shows that $\alpha$-quartz is the main mineral which constitutes the bulks of the six flintradiolarite specimens. This result is derived from its

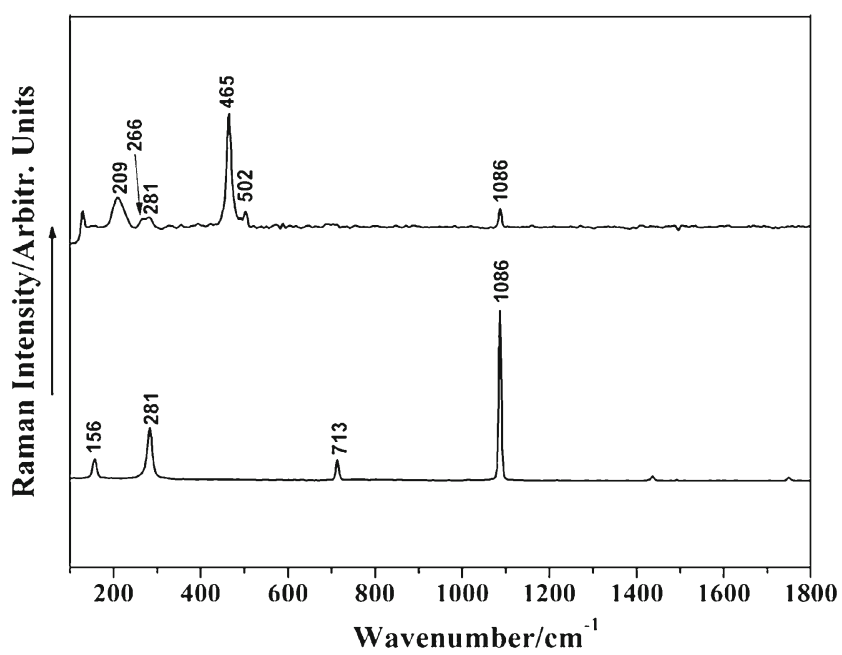

Fig. 5 FT-Raman spectra of specimen number 6 (top) and pure calcite (bottom) 
Table 1 Samples

\begin{tabular}{llll}
\hline Sample no. & Sample name & Description & Site \\
\hline 1 & 1628-Radiolarite-LP-profile-2011 & bulk (core) & (Palomas de Teba) \\
2 & 1765-AD-2-11 & bulk (burin) & (Cave of Ardales) \\
3 & 225-230-CP-3-46 & artefact-3-bulk (flake) & (Palomas de Teba) \\
4 & 1431-2011-CP-R-S-P1 & bulk (flake) & (Palomas de Teba) \\
5 & Point-492-AD-4-11-2 & Rstrata-bulk (scraper) & (Cave of Ardales) \\
6 & 1430-2011-CP-R-S-P1 & bulk (core) & (Palomas de Teba) \\
\hline
\end{tabular}

characteristic strong Raman scattering at $465 \mathrm{~cm}^{-1}$, due to the $\mathrm{SiO}_{2}$ symmetric stretching vibration, together with other two weaker features at 206 and $128 \mathrm{~cm}^{-1}$ (see Figs. 3, 4 and top of 5). The bulks of the six lithic tools also showed another Raman scattering at $501 \mathrm{~cm}^{-1}$, due to moganite (Table 1).

Figure 3 displays the FT-Raman profiles of the six lithic tools in the $400-550 \mathrm{~cm}^{-1}$ spectral range. The changes of the relative Raman intensity associated to the moganite vibration at $501 \mathrm{~cm}^{-1}$ as compared with the strong Raman feature of $\alpha$ quartz at $465 \mathrm{~cm}^{-1}$ are rather conspicuous. The FT-Raman spectra of pure $\alpha$-quartz and that of a nearly " $75 \%$ moganite+ $25 \% \alpha$-quartz" sample from Mogán (Canary Islands, Spain) are displayed in Fig. 4 for the sake of comparison. Figure 3 also shows a comparison between the FT-Raman profiles collected for specimens 1 and 2 at different spots on their surface. The resemblance between the various Raman spectral patterns recorded for each lithic tool evidences the homogeneity of the surface moganite distribution.

We recall however that some authors (Schmidt et al. 2012; Schmidt et al. 2013) have recently reported on a second Raman feature, at $503 \mathrm{~cm}^{-1}$, commonly observed in chalcedony samples and resulting from silanol $(\mathrm{SiOH})$ groups, which interferes with the main moganite band at $501 \mathrm{~cm}^{-1}$. This overlap can make the Raman spectroscopic quantification in the presence of silanol groups difficult. These authors recommended that silica rocks are heat-treated prior to their Raman analysis at a minimum of $600^{\circ} \mathrm{C}$ (but better at 700 or $800^{\circ} \mathrm{C}$ ) for silanol "dehydration". This heat-treatment, in our opinion, may be for sure a satisfactory procedure when studying flint or chert samples of a "geological origin". But it is not of practical use when studying lithic tools which were manufactured by men several thousands of years ago.

On the other hand, Fig. 5 display the FT-Raman spectrum of specimen number 6 , in the $100-1,800 \mathrm{~cm}^{-1}$ spectral range, together with that of pure calcite. The observation of a weak Raman scattering at $1,086 \mathrm{~cm}^{-1}$ in some of these lithic tools, and a second weaker Raman feature at $281 \mathrm{~cm}^{-1}$, is indicative of the presence of a calcite crust.

Advanced methodology for x-ray diffraction allows the study/analysis of polycrystalline materials if there is at least one relatively flat surface. The polycrystalline patterns were collected as described in the experimental section, and the data were further treated by the Rietveld method to obtain the mineralogical quantitative phase analyses. Figures 6 and 7
Fig. 6 Rietveld plot of number 1 as an example of a high-content moganite lithic tool. The inset highlights the $2 \theta$ region where moganite diffraction peaks are more intense and unoverlapped

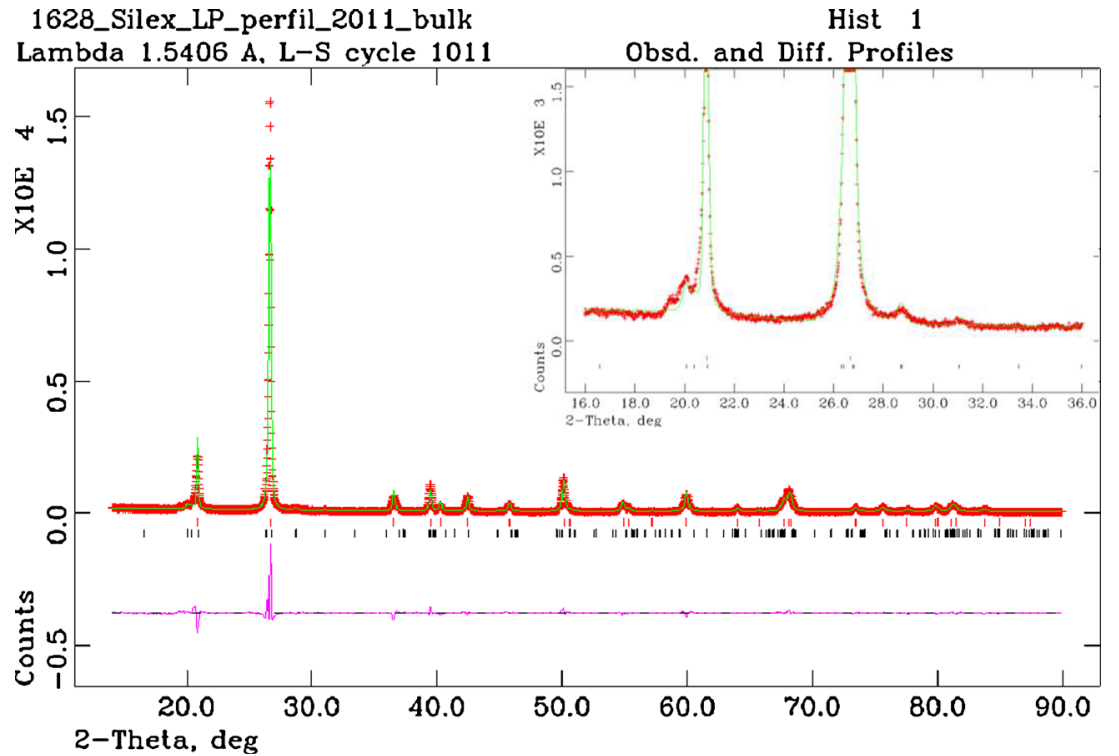


Fig. 7 Rietveld plot of number 5 as an example of a low-content moganite lithic tool. The inset highlights the $2 \theta$ region where moganite diffraction peaks are more intense and unoverlapped

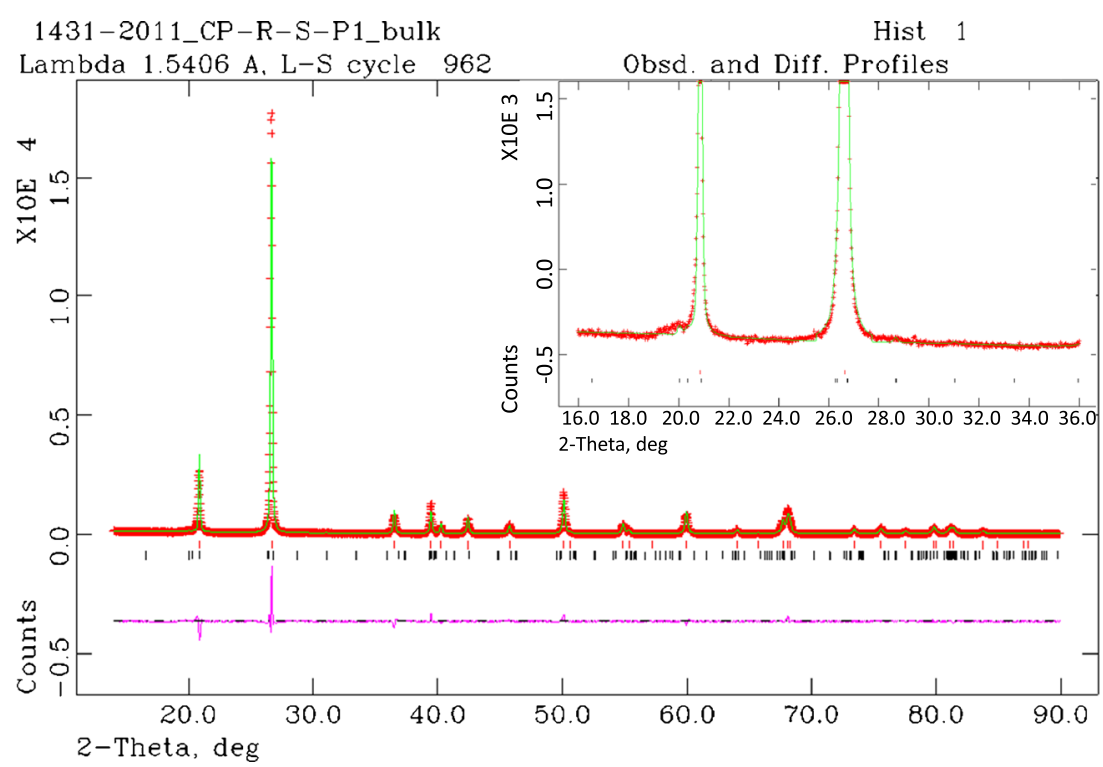

display the Rietveld plots of two lithic tools as examples of high- and low-content moganite objects, respectively. Table 2 reports the phase analyses of the six studied lithic tools. It can be seen than two lithic tools (numbers 1 and 2) have relatively high moganite contents, close to $15 \mathrm{wt} \%$. This result is in very good agreement with the Raman study as these objects displayed the strongest Raman scattering at $501 \mathrm{~cm}^{-1}$ (see Fig. 3). On the other hand, the remaining lithic tools have a much smaller moganite content, ranging between 1.4 and $4.0 \mathrm{wt} \%$, in close agreement with their Raman spectra where the $501 \mathrm{~cm}^{-1}$ scattering is much weaker. Furthermore, five of the six flints are determined to be pure silicon dioxide objects. However, number 6 lithic tool also contains $2.4 \mathrm{wt} \%$ of calcite which may be due to a small amount of surface deposited calcite.

The diffraction peak shape for $\alpha$-quartz was found to be anisotropic (i.e. $h k l$-dependent). This was modelled by the pseudo-Voigt function by refining GW (the Gaussian part), LY (the Lorentzian part) and STEC (the anisotropic correction of the Lorentzian width) along [001] direction. Moganite phase is in low contents, and their diffraction peaks are strongly overlapped with those of $\alpha$-quartz. Thus, its peak shape was isotropically modelled. Table 2 also reports the final values used in the Rietveld analysis. As expected, the two samples with higher moganite contents showed the large anisotropic broadening for $\alpha$-quartz, i.e. larger STEC values (see Table 2). This result could be explained because moganite is present as intergrowths between the $\alpha$-quartz domains. So, higher moganite contents increase the quartz microstrain and decrease the quartz coherent diffraction domain sizes. These two features make the x-ray powder diffraction peaks of $\alpha$ quartz anisotropically broader.

Finally, it should be mentioned that polycrystalline diffraction data collection followed by Rietveld analysis is much more time consuming (between 5 and $6 \mathrm{~h}$ each sample) than Raman spectroscopy. Therefore, an experimental approach can be established for the methodological study of the flint tools in the Guadalteba County in which Raman data are collected in a first step on many lithic tools (ideally in situ, by screening the samples in the field through a suited portable

Table 2 Summary of the Rietveld analysis results for the six lithic tools under study

\begin{tabular}{|c|c|c|c|c|c|c|c|c|c|}
\hline $\begin{array}{l}\text { Sample } \\
\text { no. }\end{array}$ & $\begin{array}{l}\text { Quartz/ } \\
\text { wt } \%\end{array}$ & $\begin{array}{l}\text { Moganite/ } \\
\text { wt } \%\end{array}$ & $\begin{array}{l}\text { Quartz unit cell } \\
\text { volume } / \AA^{3}\end{array}$ & $\begin{array}{l}\text { Moganite unit } \\
\text { cell } / \AA^{3}\end{array}$ & $\begin{array}{l}\mathrm{GW}_{\mathrm{qtz}} / \\
0.01^{02}\end{array}$ & $\begin{array}{l}\mathrm{LY}_{\mathrm{qtz}} / \\
0.01^{\circ}\end{array}$ & $\begin{array}{l}\text { STEC }_{\mathrm{qtz}} / \\
0.01^{\circ}\end{array}$ & $\begin{array}{l}\mathrm{GW}_{\text {mog }} / \\
0.01^{\circ 2}\end{array}$ & $\begin{array}{l}\mathrm{LY}_{\text {mog }} / \\
0.01^{\circ}\end{array}$ \\
\hline 1 & 86.7 (5) & $13.2(3)$ & $113.40(1)$ & $455.8(1)$ & $31.5(8)$ & $74(1)$ & $-50(1)$ & $150(-)$ & $34(3)$ \\
\hline 2 & $84.8(7)$ & $15.2(4)$ & $113.56(1)$ & $452.0(4)$ & $252(3)$ & $64(2)$ & $-62(2)$ & $150(-)$ & $155(7)$ \\
\hline 3 & $95.9(2)$ & $4.1(2)$ & $113.19(1)$ & $454.0(-)$ & $23.8(5)$ & $44.5(6)$ & $-26(1)$ & $150(-)$ & $20(-)$ \\
\hline 4 & $98.0(1)$ & $2.0(1)$ & $113.34(1)$ & $454.0(-)$ & 23.9 (4) & $50.9(5)$ & $-30(1)$ & $150(-)$ & $20(-)$ \\
\hline 5 & $97.9(1)$ & $2.1(2)$ & $113.17(1)$ & $454.0(-)$ & $40.8(6)$ & $38.0(6)$ & $-22(1)$ & $150(-)$ & $20(-)$ \\
\hline $6^{*}$ & 94.5 (2) & $3.1(2)$ & $113.12(1)$ & $454.0(-)$ & $123.6(1)$ & $16.5(8)$ & $-15(1)$ & $150(-)$ & $20(-)$ \\
\hline
\end{tabular}

\footnotetext{
${ }^{*}$ This sample also contains 2.4 (1) wt $\%$ of calcite
} 
Raman spectrometer) and then selected specimens are subsequently analysed in the laboratory by means of Rietveld methodology for crosschecking. The final goal of such a systematic archaeometric study of the manufactured lithic tools is to establish a broad database including visual appearance, Raman spectroscopic data, moganite weight content and microstructure information for the future studies of the possible source areas of raw materials.

\section{Conclusions}

Raman spectroscopy allowed us to clearly distinguish between $\alpha$-quartz and moganite in a series of Palaeolithic chert-manufactured specimens, revealing noticeable differences in the qualitative content ratio of these two microcrystalline $\mathrm{SiO}_{2}$ polymorphic phases among the various lithic tools under analysis.

$\mathrm{X}$-ray diffraction data were also nondestructively taken on the same lithic tools. Further, Rietveld quantitative phase analyses allowed determining the precise moganite weight content in each chert-manufactured tool. The variable moganite $/ \alpha$-quartz ratio in manufactured flint and radiolarite prehistoric artefacts unearthed in different archaeological sites of the Guadalteba County may provide valuable information to assess the possible geological sources of the corresponding raw materials. As for the six studied samples, the weight content of moganite ranged between 2 and $15 \mathrm{wt} \%$.

In summary, the combined use of FT-Raman spectroscopy and Rietveld refinement of high-quality x-ray diffraction of bulk lithic tools constitutes a useful and nondestructive experimental strategy for the methodological study of siliceous stone industries manufactured by men in the prehistory, and may help in determining the source areas of raw materials.

\begin{abstract}
Acknowledgments Research at the Universities of Málaga and Cádiz was supported by Junta de Andalucía, through funding the FQM-159, FQM-113 and HUM-440 scientific groups. We also acknowledge the help by part of the students of the "Escuela Taller de Peñarrubia", sponsored by the "Guadalteba County Consortium", both in regards to the on-site works and the subsequent classification of the findings in the archaeology workroom. Financial and technical support from the Stiftung Neanderthal Museum is also acknowledged. We finally thank José Bello for providing us with moganite-rich samples from Mogán (Canary Islands, Spain).
\end{abstract}

\section{References}

Bustillo MA (2001) Aparición y significado de la moganita en las rocas de la sílice: una revisión. J Sediment Res 71:436-443

Bustillo MA, Pérez-Jiménez JL, Fort R (2007) Deterioro de Sílex en Canteras Históricas y Muestras Líticas. MACLA 7:18
Bustillo MA, Pérez-Jiménez JL, Alonso-Zarza AM, Furio M (2012) Moganite in the Chalcedony varieties of continental cherts (Miocene, Madrid Basin, Spain). Spectrosc Lett 45:109-113

Carbonell E, Márquez B, Mosquera M, Olí A, Rodríguez XP, Sala R, Vergés JM (1999) "El Modo 2 en Galería. Análisis de la industria lítica y sus procesos técnicos" in Atapuerca: ocupaciones humanas y paleoecología del yacimiento de Galería, ed. Junta de Castilla y León, Consejería de Educación y Cultura, Valladolid, 1st edn., 390

Clark G (1998) World prehistory: in new perspective, 3rd edn. Cambridge University Press, New York, ISBN: 052129178X

Flörke OW, Jones JB, Schmincke HU (1976) A new microcrystalline silica from Gran Canaria. Z Kristallogr 143:156-165

Frondel C (1962) The system of mineralogy, vol. III: silica minerals. Wiley, New York

Gliozzo E, Grassi N, Bonanni P, Meneghini C, Tomei MA (2011) Gemstones from Vigna Barberini at the Palatine Hill (Rome, Italy). Archaeometry 53:469-489

Götze J, Nasdala L, Kleeberg R, Wenzel RM (1998) Occurrence and distribution of "moganite" in agate/chalcedony: a combined microRaman, Rietveld and cathodoluminescence study. Contrib Mineral Petrol 133:96-105

Graetsch HA, Grünberg JM (2012) Microstructure of flint and other chert raw materials. Archaeometry 54:18-36

Gutiérrez Mas JM, Martín Algarra A, Domínguez-Bella S, Moral JP (1991), Introducción a la Geología de la provincia de Cádiz, Ed. University of Cádiz, ISBN: 978-84-7786-050-1

Heaney PJ (1995) Moganite as an indicator for vanished evaporites: a testament reborn? J Sediment Res A65:633-638

Heaney PJ, Post JE (1992) The widespread distribution of a novel silica polymorph in microcrystalline quartz varieties. Science 255:441443

Heaney PJ, Post JE (2001) Evidence for an I2/a to Imab phase transition in the silica polymorph moganite at $570 \mathrm{~K}$. Am Mineral 86:13581366

Hernández V, Jorge-Villar SE, Capel Ferrón C, Medianero FJ, Ramos J, Weniger GC, Domínguez-Bella S, Linstaedter J, Cantalejo P, Espejo M, Durán Valsero JJ (2012) Raman spectroscopy analysis of Palaeolithic industry from Guadalteba terrace river, Campillos (Guadalteba county Southern of Iberian Peninsula. J Raman Spec 43:1651-1657

Jambor JL, Burke EAJ, Grew ES, Puziewicz J (1993) New mineral names. Am Mineral 78:672-678

Kingma KJ, Hemley RJ (1994) Raman spectroscopic study of microcrystalline silica. Am Mineral 79:269-273

Laplace G (1975) La typologie analytique et structurale: Base rationnelle d'étude des industries lithiques et osseuses. Colloques Nationaux du Centre National de la Reserche Scientifique, Ed. CNRS, Marseille, 932: 91-141

Larson AC, Von Dreele RB (2000) General Structure Analysis System (GSAS), Los Alamos National Laboratory Report LAUR

Maslen EN, Streltsov VA, Streltsova NR, Ishizawa N (1995) Electron density and optical anisotropy in rhombohedral carbonates. III. Synchrotron X-ray studies of $\mathrm{CaCO}_{3}, \mathrm{MgCO}_{3}$ and $\mathrm{MnCO}_{3}$. Acta Cryst B51:929-939

Medianero FJ, Ramos J, Palmqvist P, Weniger GC, JRiquelme JA, Espejo M, Cantalejo P, Aranda A, Pérez-Claros JA, Figueirido B, Espigares P, Ros-Montoya S, Torregrosa V, Linstädter L, Cabello L, Becerra S, Ledesma P, Mevdev I, Castro A, Romero M, Martínez-Navarro B (2011) The karst site of Las Palomas (Guadalteba County, Málaga, Spain): a preliminary study of its Middle-Late Pleistocene archaeopaleontological record. Quatern Int 243:127-136

Olivares M, Tarriño A, Murelaga X, Baceta JI, Castro K, Etxebarria N (2009) Non-destructive spectrometry methods to study the distribution of archaeological and geological chert samples. Spectrochim Acta A 73:492-497 
Pretola JP (2001) A feasibility study using silica polymorph ratios for sourcing chert and chalcedony lithic materials. J Archaeol Sci 28: 721-739

Schmidt P, Bellot-Gurlet L, Slodczyk A, Fröhlich F (2012) A hitherto unrecognised band in the Raman spectra of silica rocks: influence of hydroxylated $\mathrm{Si}-\mathrm{O}$ bonds (silanole) on the Raman moganite band in chalcedony and flint $\left(\mathrm{SiO}_{2}\right)$. Phys Chem Minerals 39:455-464

Schmidt P, Bellot-Gurlet L, Léa V, Sciau P (2013) Moganite detection in silica rocks using Raman and infrared spectrocopy. Eur J Mineral 25(5):797-805

Tarriño A, Olivares M, Etxebarria N, Baceta JI, Larrasoaña JC, Yusta I, Pizarro JL, Cava A, Barandiarán I, Murelaga X (2007) El sílex de tipo "Urbasa" Caracterización petrológica y geoquímica de un marcador litológico en yacimientos arqueológicos del Suroeste europeo durante el Pleistoceno superior y Holoceno inicial. Geogaceta 43:127-130
Thompson P, Cox DE, Hastings JB (1987) Rietveld refinement of Debye-Scherrer synchrotron X-ray data from $\mathrm{Al}_{2} \mathrm{O}_{3}$. J Appl Cryst 20:79-83

Vallespí E (1986), El Paleolítico inferior y medio en Andalucía in Homenaje a Luis Siret (1934-1984). Ed. Junta de Andalucía, Consejería de Cultura, pp. 59-66. ISBN: 84-505-3511-5

Vallespí E (1986), Cultura de las graveras y comienzos del Achelense Ibérico in Estudios en homenaje al Dr. Antonio Beltrán Martínez, Ed. University of Zaragoza, Zaragoza, pp. 147-157. ISBN: 84-6004366-5

Vallespí E (1992) Las industrias Achelenses de Andalucía: Ordenación y Comentarios. SPAL 1:61-78

Will G, Bellotto M, Parrish W, Hart M (1988) Crystal structures of quartz and magnesium germanate by profile analysis of synchrotron-radiation high-resolution powder data. J Appl Cryst 21:182-191 